\title{
Chemical Composition, Antibacterial and Antioxidant Activities of Thymus Praecox
}

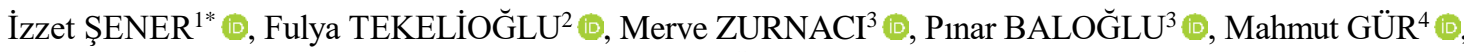 \\ Kerim GÜNEY ${ }^{5}$ \\ ${ }^{1}$ Kastamonu University, Food Engineering, Kastamonu, TURKEY \\ ${ }^{2}$ Kastamonu University, Department of Chemistry, Kastamonu, TURKEY \\ ${ }^{3}$ Kastamonu University, Central Research Laboratory, Kastamonu, TURKEY \\ ${ }^{4}$ Kastamonu University, Department of Forest Industrial Engineering, Kastamonu, TURKEY \\ ${ }^{5}$ Kastamonu University, Department of Forest Engineering, Kastamonu, TURKEY \\ "Corresponding Author: isener@kastamonu.edu.tr
}

Received Date: 11.11.2020

Accepted Date: 17.03.2021

\section{Abstract}

Aim of Study: It was aimed to determine the chemical composition, antioxidant and antibacterial activity of the Thymus praecox which distributed in the Kastamonu region.

Material and methods: Spectroscopic and chromotographic analysis were applied in the determination of the chemical composition. Thyme extracts were prepared using five different solvents. In Thymus praecox, the presence of flavonoids using HPLC and the chemical content of essential oil using GC-MS were investigated. The analyses of the mineral were determined in leaf and stem of thyme by ICP-OES. Antioxidant capacity was determined using two methods such as DPPH free radical scavenging and $\mathrm{H}_{2} \mathrm{O}_{2}$ scavenging. Antibacterial activity on ten bacteria, Gram (+) and Gram (-) was tested using the disc diffusion method.

Main results: Experimental results showed that thyme extracts have antibacterial activities against some bacteria. As a result, it was found that the most affected bacteria was $S$. aureus. Inhibition zone diameter was determined to be between $8-12 \mathrm{~mm}$. The effect of solvent on antibacterial activity, antioxidant capacity, total phenolic and total flavonoid amounts were observed.

Highlights: These results showed that $T$. praecox has the potential to be used as a natural antimicrobial and antioxidant agent, and can be used as a natural supportive treatment.

Keywords: Thymus praecox, Essential oil, Antibacterial, Antioxidant, Phenolic, Flavonoid, HPLC, GC-MS, ICP-OES

\section{Thymus Praecox'un Kimyasal Bileşimi, Antibakteriyel ve Antioksidan Aktiviteleri}

$\ddot{O} \mathbf{z}$

Çalışmanın amacı: Kastamonu bölgesinden toplanan Thymus praecox'un kimyasal bileşimini, antioksidan kapasitesini ve antibakteriyel aktivitesini belirlemektir.

Materyal ve yöntem: Kimyasal bileşimin belirlenmesinde spektroskopik ve kromatografik analizler uygulandı. Kekik özleri beş farklı çözücü kullanılarak hazırlandı. HPLC kullanılarak Thymus praecox içeriğinde bulunan flavonoidlerin varlığı ve GC-MS kullanılarak uçucu yağın kimyasal içeriği araştırıldı. Kekiğin yaprak ve sapındaki mineral analizleri ICP-OES ile belirlendi. Antioksidan kapasite, DPPH serbest radikal temizleme yöntemi ve $\mathrm{H}_{2} \mathrm{O}_{2}$ süpürme yöntemi gibi iki yöntem kullanılarak belirlendi. On bakteri, Gram (+) ve Gram (-) üzerindeki antibakteriyel aktivite disk difüzyon yöntemi kullanılarak test edildi.

Temel sonuçlar: Deneysel sonuçlar, kekik ekstraktlarının bazı bakterilere karşı antibakteriyel aktiviteye sahip olduğunu göstermiştir. Sonuç olarak, en çok etkilenen bakterinin $S$. aureus olduğu bulundu. İnhibisyon zon çapının 8-12 $\mathrm{mm}$ arasında olduğu belirlendi. Çözücülerin antibakteriyel aktivite, antioksidan kapasite, toplam fenolik ve toplam flavonoid miktarları üzerine etkisi gözlendi.

Araştırma vurguları: Çalışmalar T. praecox'un doğal bir antimikrobiyal ve antioksidan ajan olarak kullanılma potansiyeline sahip olduğunu ve doğal bir destek tedavisi olarak kullanılabileceğini gösterdi.

Anahtar kelimeler: Thymus praecox, Uçucu yağ, Antibakterial, Antioxidant, Fenolic, Flavonoid, HPLC, GC-MS, ICP-OES 


\section{Introduction}

Plants exhibit very versatile biological effects on human metabolism through their components such as flavonoid, alkaloid, terpenoid, tannin, berberine, quinine, and emetine (Njume et al., 2009; Hussain et al., 2011). These metabolites obtained by medicinal and aromatic plants have an ecological and biological role (Llorens et al., 2014). As a result of this, the products obtained from medicinal and aromatic plants have taken place in many applications such as food conservation, pharmaceutical, and alternative treatment (Vital et al., 2011; Khan et al., 2019). The flavonoids and phenolic compounds contained in thyme have significant potential for the development of industrial products in medicine and cosmetics due to their antioxidant and antibacterial properties (Khalkho et al., 2015).

The thyme content varies depending on its origin, environmental conditions, stage of development, and harvest time of the plant (Markovic at al., 2011). Since flavonoids and phenolic compounds are mostly present in the leaves, flowers and woody parts of the plants (Kähkönen et al., 1999), essential oil extracts obtained by methods such as extraction and distillation are used for various purposes after drying these parts of the plants (Botsoglu et al., 2003). There are many species of thyme belong to Lamiaceae which is known as a rich source of phenolic and flavonoids (Phippen et al., 1998). One of the most important breeds of the Lamiaceae family is Thymus, which contains about 110 common species (Morales, 1997). The Thymus sp. is among the most widespread species in Turkey and the world (Avci, 2011; Panizzi et al., 1993). Thymus sp. grows in grassy field shores, forest edges, meadows and rocky, and mountainous areas where high soil temperature (Beata et al., 2015). The Thymus sp. has carminative, antioxidant, pharmacological, and very wide biological properties (Stahl-Biskup et al., 2002). The genus Thymus contains about many subspecies and varieties (De Martino et al., 2009). Among these, Thymus praecox has a serious interest among medicinal and aromatic plants because of its rich chemical components (Balouiri et al., 2016).

In the present study, $T$. praecox were studied with the following objectives: 1) to identify the chemical composition; 2) to determine antioxidant activity in the different solvent; 3 ) to determine antioxidant activity in the different solvent. Its chemical components were determined by using spectroscopic and chromatographic methods. The activities of $T$. praecox extracts against ten bacteria were determined by a disc diffusion method. The antioxidant activities of ethanol (99\%), methanol (99\%), methanol-water (65\%-35\%), ethyl acetate (99\%) and pure water extracts of $T$. praecox were evaluated by various antioxidant assay like DPPH ad $\mathrm{H}_{2} \mathrm{O}_{2}$ radical scavenging assay.

\section{Material and Methods \\ Thyme Samples}

In this study, T. praecox, which is one of the most used aromatic plants, has been selected. The thyme plant was taken from the rocky area on Devrekani-Abana road in the morning of July 2017. The collected thyme samples were dried for 4 weeks. T. praecox was identified by Assist. Prof. Dr Kerim GÜNEY, Department of Forest Engineering, Faculty of Forestry, Kastamonu University.

\section{Isolation of Essential Oil}

Essential oil of the Thymus praecox was obtained by hydro distillation process using a Clevenger's type. Essential oil was storage in refrigerator at $4{ }^{\circ} \mathrm{C}$ (Özkan et.al., 2018).

\section{Extraction Process}

The thyme samples were cleaned, dried, and powdered (stem-leaf-flower) before extraction (ISOLAB). For the extraction process; Soxhlet device (M-TOPO) and Rotary evaporator device (HEIDOLPH) were used. 10-30 g sample was taken for each extraction and placed in soxhlet cartridge. For this purpose, five different solvents were used: ethanol (99\%), methanol (99\%), methanol-water (65\%-35\%), ethyl acetate (99\%), and pure water. After the extraction process was completed in 24 hours the solvent was removed in the rotary evaporator. The experimental process followed throughout the study is shown schematically in Figure 1.

\section{Apparatus \\ Inductively coupled plasma-optical emission spectrometer (ICP-OES, Spectro}


Blue II), one of the commonly used techniques for the analysis of trace elements, was preferred for the determination of the elements in the thyme plant. Microwave digestive was carried out with the Milestone Ethos TC system using a maximum 1300 psi pressure and a maximum $300{ }^{\circ} \mathrm{C}$ temperature procedure. Gas chromatography-mass spectrometry (GC-MS, Shimadzu QP 2010 ULTRA) was used to detect of essential oil componenent UV-61 100 PCS Double Beam Spectrophotometer (UV-Visible) and highperformance liquid chromatography (HPLC, Shimadzu, LC20-A Prominence) were used to detect total flavonoid amounts.

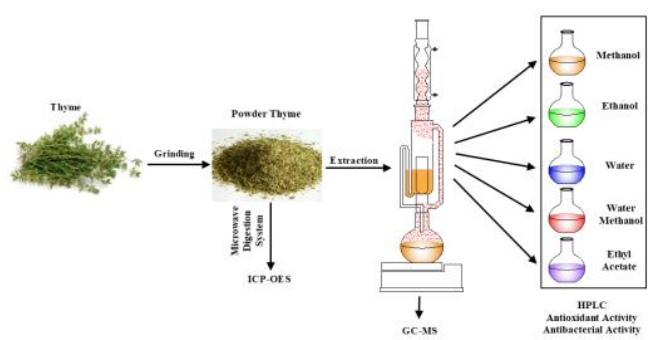

Figure 1. Shematic diagram of experimental process

\section{Mineral Analysis}

Spectro Blue II model ICP-OES device was used to determine the trace elements. Operating parameters and hardware of ICPOES are given in Table 1. For the microwave digestion method, Milestone Ethos TC closed vessel microwave device was used. The argon gas used is certified $99.996 \%$ purity.

Table 1. Operating parameters and hardware of ICP-OES

\begin{tabular}{ll}
\hline Instrument & Spectro Blue II \\
\hline Pump Speed (rpm) & 30 \\
\hline Plasma Power (W) & 1200 \\
\hline Spray chamber & Cyclonic \\
\hline Plasma View Mode & Axial and radial \\
\hline Plasma Torc & Quartz \\
\hline Coolant Flow (L/min) & 13 \\
\hline $\begin{array}{l}\text { Auxiliary Gas Flow } \\
\text { (L/min) }\end{array}$ & 0.8 \\
\hline Nebulizer Flow (L/min) & 0.8 \\
\hline Software & Icp Analyzer Pro \\
\hline
\end{tabular}

\section{GC-MS Analysis}

The analysis of the essential oil of $T$. praecox was carried out by GC-MS (Gas Chromatography-Mass Spectroscopy). The components were identified using GC-MS Wiley Data Library according to their retention time. The used column of the device is the RTX-5MS Capillary column $(30 \mathrm{~m} \cdot 0.25$ $\mathrm{mm}$; coating thickness $0.25 \mu \mathrm{m}$ ). Analytical conditions were injector temperature $250{ }^{\circ} \mathrm{C}$; carrier gas Helium at $1 \mathrm{~mL} / \mathrm{min}$; injection mode: split, split ratio 1:10; volume injected: $1 \mu \mathrm{L}$ solution of the oil in hexane; and oven temperature programmed from $40{ }^{\circ} \mathrm{C}$ to 240 ${ }^{\circ} \mathrm{C}$ at $4{ }^{\circ} \mathrm{C} / \mathrm{min}$, pressure: $100 \mathrm{kPa}$, purge flow: $3 \mathrm{~mL} / \mathrm{min}$. The MS scan conditions used included a transfer line temperature of $250^{\circ} \mathrm{C}$, an interface temperature of $250^{\circ} \mathrm{C}$, and an ion source temperature of $200^{\circ} \mathrm{C}$.

\section{HPLC Analysis}

HPLC analysis, Shimadzu LC20-AT Prominence, Inertsil ODS-3 Reverse Phase (5 $\mu \mathrm{m}-25 \times 4.6 \mathrm{~mm}$ ) column was used and it was run at $30{ }^{\circ} \mathrm{C}$ column temperature. Flavonoid measurements were determined at $280 \mathrm{~nm}$ with $20 \mu \mathrm{L}$ injection volume. Standard solutions were prepared with $100 \%$ methanol and the flow rate was determined as 0.4 $\mathrm{mL} / \mathrm{minute}$.

\section{Antibacterial Activity}

Antibacterial activities of thyme extracts obtained with 5 different solvents were tested against ten microorganisms. The used microorganisms are five Gram (+) and five Gram (-) such as Staphylococcus aureus ATCC 25923 (+), E. coli (-), Enterococcus faecium (+), Serratia marcescens (-), alpha hemolytic Streptococcus (+), Staphylococcus epidermidis (+), Enterococcus faecium (+), Pseudomonas aeruginosa (-), Listeria monocytogenes ATCC 7644 (+), Salmonella kentucky (-), Enterobacter aerogenes ATCC 13048 (-). A disc diffusion test was applied according to the literature ${ }^{17}$ by using two different concentrations $(5-50 \mathrm{mg} / \mathrm{L})$ for the purpose to find the concentration sensitive to bacteria (Altuner, et al., 2015). 


\section{Antioxidant Capacity}

Thyme extracts were prepared with the soxhlet extraction using five solvents such as ethanol (99\%), methanol (99\%), methanolwater (65\%-35\%), ethyl acetate $(99 \%)$ and pure water. Their antioxidant activities were determined using two methods such as $\mathrm{H}_{2} \mathrm{O}_{2}$ scavenging method and DPPH free radical scavenging method. Total phenolic and flavonoid amounts were obtained according to the Folin-Ciocalteu and aluminium chloride colourimetric procedures.

\section{Total Phenolic Amounts}

It was applied to Slinkard and Singleton procedures with Folin-Ciocalteu in determining total phenolic amounts (Slinkard et al., 1977). Gallic acid is used as a standard. The resulting calibration equation is $\mathrm{y}=$ $0.0016 \mathrm{x}+0.1683$. The wavelength of measurements is $760 \mathrm{~nm}$.

\section{Total Flavonoid Amounts}

Total flavonoid amounts were determined according to aluminium chloride colourimetric procedure (Chang et al., 2002). Solutions were prepared from plant extracts in different concentrations. Absorbance values were measured at $415 \mathrm{~nm}$. Total flavonoid amounts were calculated with the obtained quercetin calibration curve data (the calibration equation for quercetin: $\mathrm{y}=$ $0.0017 x+0.1457)$.

\section{DPPH Free Radical Scavenging Assay}

DPPH free radical scavenging assay was performed according to Blois method (Blois et al., 1958). The basis of this method is that natural and synthetic antioxidants remove
DPPH (2,2-Diphenyl-1-picrylhydrazyl) radical. The free radical scavenging assay was calculated using absorbance values at the end of 30 minutes at $517 \mathrm{~nm}$. Standard (Ascorbic acid) and free radical scavenging capacities of extracts and were calculated as $\mathrm{IC}_{50}(\mathrm{mg} / \mathrm{L})$. $\mathrm{IC}_{50}$ values were calculated using the graphs obtained from the scavenging and remaining equations are given:

Remaining $(\%)=\left[1-\left(\right.\right.$ Acontrol $_{-}$A sample $\left.) / A_{\text {control }}\right] \times 100$,

Scavenging $(\%)=\left[\left(\mathrm{A}_{\text {control }}-\mathrm{A}_{\text {sample }}\right) / \mathrm{A}_{\text {control }}\right] \times 100$.

\section{Hydrogen Peroxide Scavenging Assay}

For determining $\mathrm{H}_{2} \mathrm{O}_{2}$ scavenging capacity was applied Ruch procedure (Ruch et al.,1989). According to this procedure, $3.5 \mathrm{~mL}$ of the extracts or standard were mixed with $500 \mu \mathrm{L}$ of $\mathrm{H}_{2} \mathrm{O}_{2}$. Absorbance was measured at $230 \mathrm{~nm}$ wavelength 10 minutes after the addition of hydrogen peroxide.

\section{Results \\ HPLC Analyses}

As seen in Table 2, eight different flavonoids such as eleutheroside, taxifolin, naringin, myricetin, quercetin, butein, luteolin and campherol in the extracts were investigated using HPLC method. Flavonoid amounts in extracts determined at the range of 15.300 and 70.771 (eleutheroside), 14.462 and 58.518 (taxifolin), 75.776 and 2028.88 (myricetin), 84.374 and 2578.03 (naringin), 46.641 and 3885.4 (quercetin), 5.603 and 40.756 (butein), 2.329 and 82.081 (luteolin), 18.512 and 32.000 (campherol) as $\mu \mathrm{g} \mathrm{g}^{-1}$ plant. Among the tested flavonoids, the highest flavonoid concentration was found in naringin in the methanol-water extract.

Table 2. HPLC analyses results of flavonoids

\begin{tabular}{lllllllll}
\hline \multirow{2}{*}{ Solvents } & \multicolumn{7}{c}{ Flavonoids $\left(\mu \mathrm{g} . \mathrm{g}^{-1}\right.$ plant $)$} \\
\cline { 2 - 9 } & Eleutheroside Taxifolin & Naringin & Myricetin & Quercetin & Butein & Luteolin & Campherol \\
\hline Pure Water & 36.096 & 25.514 & 1184.9 & 2028.880 & 3885.400 & 40.756 & 41.502 & - \\
\hline Ethanol & 70.771 & 28.545 & 2578.030 & 129.900 & 65.351 & 5.603 & 31.807 & 32.000 \\
\hline Etyl Acetate & 15.300 & 58.518 & 84.374 & 75.776 & 90.672 & 18.534 & 21.514 & 28.664 \\
\hline Methanol-Water & 23.530 & 14.462 & 4287.380 & 551.530 & 46.641 & - & 2.329 & - \\
\hline Methanol & 40.015 & 44.480 & 2222.800 & 55.979 & 284.71 & 27.540 & 82.081 & 18.512 \\
\hline
\end{tabular}

(-) Flavonoid was undetected 
GC-MS Analysis

As a result of the GC-MS analysis was performed, 50 compounds were found in the essential oil of $T$. praecox and the main components were given in Table 3 . The main components detected $\alpha$-terpinenyil-acetate
(\%15.89), $\delta$-Thujone (\%12.71), $\alpha$-pinene (\%10.46), 1,8-Cineole (\%7.49) and Camphor (\%6.89). In the essential oil of thyme have been mostly detected terpene and terpenederived compounds.

Table 3. Main components of thyme essential oil.

\begin{tabular}{llc}
\hline Components & Area $\%$ & Retention Time \\
\hline$\alpha$-terpinyl-acetate & 15.89 & 24.923 \\
\hline$\delta$-Thujone & 12.71 & 15.876 \\
\hline$\alpha$-pınene & 10.46 & 9.066 \\
\hline 1,8 -Cineole & 7.49 & 12.892 \\
\hline Camphor & 6.89 & 17.348 \\
\hline Thujone & 5.04 & 16.285 \\
\hline Caryophyllene & 4.61 & 27.282 \\
\hline D-Limonene & 3.99 & 12.803 \\
\hline Camphene & 2.66 & 9.595 \\
\hline Germacrene-D & 2.43 & 29.296 \\
\hline Endo-Borneol & 2.21 & 18.193 \\
\hline
\end{tabular}

\section{Mineral Analyze}

In thyme (leaf, flower and stem), the highest concentration was found to be Calcium $(\mathrm{Ca})$ and the lowest concentration was Chromium (Cr). In thyme, the contents of $\mathrm{Ca}, \mathrm{Al}, \mathrm{Fe}, \mathrm{K}, \mathrm{Cr}, \mathrm{Mn}, \mathrm{Ni}, \mathrm{Cu}, \mathrm{Na}, \mathrm{Mg}, \mathrm{Ba}, \mathrm{Se}$, and $\mathrm{Zn}$ were found as $40000.83,100.981$,
$93.0, \quad 13.800,0.121,6.510,0.729,0.970$, $100.944,2300,12.212,0.403,4.134$ and $0.178 \mu \mathrm{g} . \mathrm{g}^{-1}$, respectively. Relative Standard Deviation (RSD \%) values calculated based on the results obtained were given in Table 4. It was seen that in Table 5 RSD \% values obtained from all processes are $\leq 9.189$.

Table 4. The results of ICP-OES analysis ( $\mu \mathrm{g} \cdot \mathrm{g}^{-1}$ plant $)(n=3)$.

\begin{tabular}{llll}
\hline $\mathbf{A l}$ & $\mathbf{C a}$ & $\mathbf{F e}$ & $\mathbf{K}$ \\
\hline $100.981 \pm 0.023$ & $40000.83 \pm 0.045$ & $93.0 \pm 0.015$ & $13.800 \pm 1.059$ \\
\hline $\mathbf{C r}$ & $\mathbf{M n}$ & $\mathbf{N i}$ & $\mathbf{C u}$ \\
\hline $0.121 \pm 0.046$ & $6.510 \pm 1.000$ & $0.729 \pm 0.174$ & $0.970 \pm 0.166$ \\
\hline $\mathbf{N a}$ & $\mathbf{M g}$ & $\mathbf{B a}$ & $\mathbf{S e}$ \\
\hline $100.944 \pm 0.005$ & $2300 \pm 0.120$ & $12.212 \pm 0.896$ & $0.403 \pm 0.245$ \\
\hline $\mathbf{Z n}$ & $\mathbf{P b}$ & & \\
\hline $4.134 \pm 1.468$ & $0.178 \pm 0.164$ & & \\
\hline
\end{tabular}

Table 5. RSD results $(\mathrm{n}=3)$

\begin{tabular}{lllllll}
\hline $\mathbf{A l}$ & $\mathbf{C a}$ & $\mathbf{F e}$ & $\mathbf{K}$ & $\mathbf{N a}$ & $\mathbf{M g}$ & $\mathbf{B a}$ \\
\hline 1.143 & 0.113 & 1.597 & 0.767 & 0.271 & 0.518 & 0.734 \\
\hline $\mathbf{C r}$ & $\mathbf{M n}$ & $\mathbf{N i}$ & $\mathbf{C u}$ & $\mathbf{Z n}$ & $\mathbf{P b}$ & $\mathbf{S e}$ \\
\hline 3.778 & 1.536 & 2.386 & 1.712 & 3.551 & 9.189 & 6.065 \\
\hline
\end{tabular}

\section{Antibacterial Activity}

The activities of the five thyme extracts to the bacteria were investigated and observed to be inhibited at different ratios against the bacterium. In antibacterial experiments, among the selected bacteria, thyme extracts were more resistant to $S$. aureus with inhibition zone in the range of $0.6-18 \mathrm{~mm}$. The highest inhibition zone diameter $(8-18 \mathrm{~mm})$ was obtained in Staphylococcus aureus ATCC 25923 bacteria. S. aureus was inhibited an $18 \mathrm{~mm}$ inhibition zone in the pure water 
extract. The other inhibition zones of $S$. aureus are shown for five different solvents in Figure 2. The lowest inhibition zone diameter, respectively, were for methanol, ethanol, ethyl acetate, methanol-water and pure water extract against $S$. aureus.

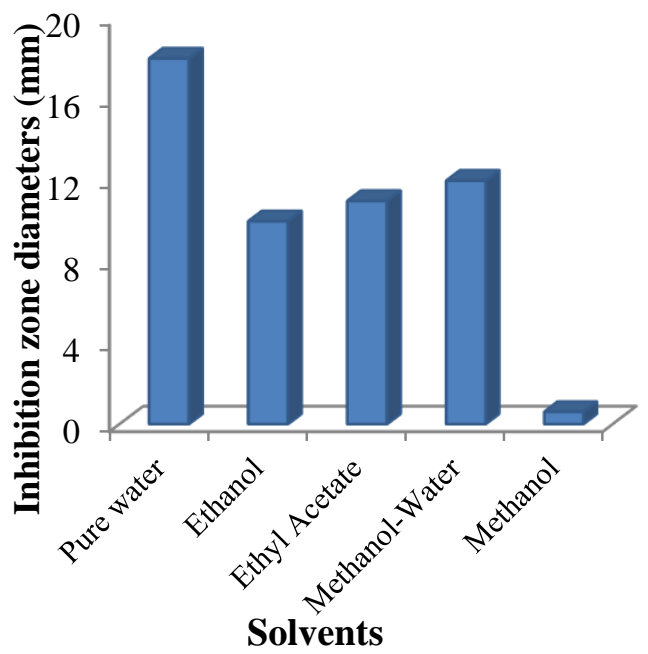

Figure 2. Inhibition zones of Staphylococcus aureus ATCC 25923 bacteria against 5 different solvents

\section{Antioxidant Activity}

DPPH and $\mathrm{H}_{2} \mathrm{O}_{2}$ scavenging assays were used to investigate the antioxidant activities of T. Praecox and it was found to vary according to the use of solvents and methods. It was embraced that the differences in total phenolic amounts affected to their antioxidant capacities. The results show that thyme extracts are more effective than ascorbic acid used as an antioxidant standard. These numerical values are given in Table 6. As seen in Table 6 , the highest phenolic content was determined in the ethanol extract (44.56) followed by the ethyl acetate extract (43.93). Furthermore, the maximum flavonoid content was also determined in ethyl acetate extract
(2.86). The DPPH and $\mathrm{H}_{2} \mathrm{O}_{2}$ scavenging activities were tested and the half-maximal inhibitory concentration $\left(\mathrm{IC}_{50}\right)$ determined as depending on extract concentration. The scavenging and remaining graphs of the DPPH assay were plotted (Figure 3) and the $\mathrm{IC}_{50}$ value of ascorbic acid was calculated using these graphs. In the DPPH free radical scavenging assay, the maximum $\mathrm{IC}_{50}$ value was determined in ethyl acetate extract (698.09) and $\mathrm{H}_{2} \mathrm{O}_{2}$ scavenging assay was also found in the methanol-water extract (1167) while the $\mathrm{IC}_{50}$ value for ascorbic acid was measured as 67.24. So that the results show that thyme extracts are more effective than ascorbic acid antioxidant standard (Table 6).
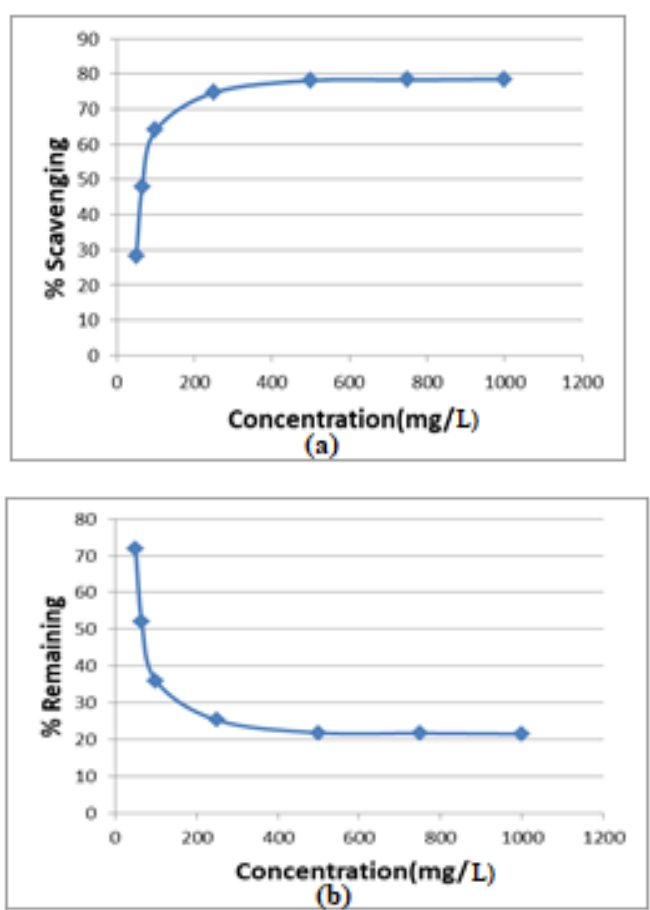

Figure 3. a) Ascorbic acid DPPH radical scavenging rates b) Ascorbic acid DPPH radical remaining rates

Table 6. Antioxidant activity, total phenolic and flavonoid content

\begin{tabular}{lcccc}
\hline Solvents & $\begin{array}{c}\text { Phenolics } \\
\left(\mu \mathrm{g} \cdot \mathrm{mL}^{-1)}\right.\end{array}$ & $\begin{array}{c}\text { Flavonoids } \\
\left(\mu \mathrm{g} \cdot \mathrm{mL}^{-1}\right)\end{array}$ & $\begin{array}{c}\mathrm{H}_{2} \mathrm{O}_{2} \mathrm{IC}_{50} \\
\left(\mu \mathrm{g} \cdot \mathrm{mL}^{-1}\right)\end{array}$ & $\begin{array}{c}\text { DPPH IC } \\
\left(\mu \mathrm{g} \cdot \mathrm{mL}^{-1}\right)\end{array}$ \\
\hline Pure water & 17.37 & 2.1 & 447 & 497.72 \\
\hline Ethanol & 44.56 & 1.04 & 396 & 517.93 \\
\hline Ethyl Acetate & 43.93 & 2.86 & 1056 & 698.09 \\
\hline Methanol-Water & 26.12 & 1.36 & 1167 & 438.76 \\
\hline Methanol & 34.87 & 2.15 & 554 & 444.74 \\
\hline
\end{tabular}




\section{Discussion}

In this study, the chemical composition, antioxidant and biological activities of $T$. praecox were investigated. The flavonoid content of thyme extracts, compounds of the essential oil of thyme and mineral content of thyme extracts were determined using HPLC, GS-MS and ICP-OES devices, respectively. Chromatographic analysis of essential oil of thyme has been found to contain many terpenes and terpene-like structures. The results of GC-MS analysis revealed that found compounds are typical components of other Thymus species (Stah-Biskup, 1991). Most of the volatile terpenoids in Thymus oils belong to the monoterpene group and sesquiterpenes are always present as a small component, with a few exceptions (Mahboubi et al., 2017). Also, terpenoids have been reported to play an important role in the biological activities of thyme oils (Mahboubi et al., 2017). Previous studies have investigated the content of chemical components in the essential oil of Thymus and have reported that the chemical composition of essential oils depends on various factors (harvest season, collection site, environmental factors, preparation and extraction method and growth process) (Zarshenas et al., 2015). In addition, previous studies were indicated that the main components of thyme species such as Origanum (Chun et al., 2005), Satureja (Oke et al., 2009), Thymbra (Delgado-Adámez et al.,2017), Thymus (Bounatirou et al., 2007; Ložienè, et al., 2007; Petrović et al., 2016) and Corydothymu (Goren et al., 2003) are important as antibacterial and antioxidant (Koparal et al., 2003).

It was seen that results of mineral analysis are similar to the results of many studies: Kıliç, S. carried out the determination of elements in five different plants including thyme and their essential oils (Kılıç et al., 2018). She has determined six elements with the ICP-OES and the lowest concentration was also found Chromium (Cr). Satyal, P. et al. investigated the mineral content in the thyme and also, they found that the lowest mineral content was in the Thymus vulgaris (Ruch et al., 1989) Furthermore, they determined that the highest concentration among the elements was $\mathrm{Ca}$.
A great deal of researches has been done on the antibacterial activities of thyme species (Stahl-Biskup et al., 2002; Jean et al., 2009) Ruiz-Navajas, Y. et al. claimed that oils from Thymus species contain important bioactive compounds with antibacterial activity on bacteria (Ruiz-Navajas et al., 2012). Among the two endemic species of thyme, $T$. piperella $\mathrm{EO}$ found that it was much more effective than T. moroderi $\mathrm{EO}$ and linked it to its chemical composition. They also emphasized that Gram-positive bacteria have a much greater effect than Gram-negative bacteria. Tepe et al. (2005) tested the antibacterial activity of Thymus hyemalis on many bacterial strains and found that they did not affect Enterobacter aerogenes, Klebsiella pneumoniae, $\quad P . \quad$ aeruginosa, $L$. monocytogenes and Pseudomonas fluorescens. They stated that the most effective microorganisms were $S$. aureus, Enterococcus faecalis, Bacillus cereus and B. subtilis. Ballester-Costa et al. (2017) suggested that the antibacterial properties of thyme stemmed from terpenes in thyme oil.

Since the antioxidant and antibacterial activities of medicinal plants largely depend on the presence of terpene and terpene-like structures in essential oil, it is clear that the main components of $\mathrm{T}$. praecox can be a valuable natural source of antioxidants for food preservation, pharmaceutical and alternative treatment purposes. $T$. praecox can be a commercial source thanks to its flavonoids. In the mineral analysis of $T$. Praecox, it was determined that it was at a level that would not pose any risk for human health and that it was acceptable for daily dose intake.

This study contributed to the literature by examining the chemical composition of $T$. praecox which is a medicinal and aromatic plant. The future study may focus on investigating the properties of different thyme species, antifungal and cytotoxic activity and investigating the relationship between chemical composition and biogeography and climate and soil parameters.

\section{Ethics Committee Approval N/A}




\section{Peer-review}

Externally peer-reviewed

\section{Author Contributions}

Conceptualization: İ.Ş., $\quad$ M.G.; Investigation: İ.Ş., M.Z., M.G., T.T.; Material and Methodology: İ.Ş., M.Z.; Supervision: İ.Ş., M.G., K.G.; Visualization: İ.Ş., M.Z.; Writing-Original Draft: İ.Ş., M.Z., M.G.; Writing-review\&Editing: I.Ş., M.Z., M.G.; Other: P.B., F.T. All authors have read and agreed to the published version of manuscript.

\section{Conflict of Interest}

The authors have no conflicts of interest to declare

\section{Funding}

This study has been supported within the scope of project numbered KUBAP-03/201714 by Kastamonu University, Scientific Research Projects Coordination Department.

\section{References}

Avci, A.B. (2011). Chemical variation on the essential oil of Thymus praecox ssp. scorpilii var. Laniger. International Journal of Agriculture and Biology, 13(4).

Altuner, E.M., Çeter, T., Gür, M., Güney, K., Kiran, B., Ealoma Akwieten, H., \& Soulman, S.I. (2018). Chemical Composition and Antimicrobial Activities of Cold Pressed Oils Obtained from Nettle Radish and Pomegranate Seeds. Kastamonu Üniversitesi Orman Fakültesi Dergisi, 18(3), 236-247.

Ballester-Costa, C., Sendra, E., Fernández-López, J., Pérez-Álvarez, J.A. \& Viuda-Martos, M. (2017). Assessment of antioxidant and antibacterial properties on meat homogenates of essential oils obtained from four Thymus species achieved from organic growth. Foods, 6(8), 59.

Balouiri, M., Sadiki, M. \& Ibnsouda, S.K. (2016). Methods for in vitro evaluating antimicrobial activity: A review. Journal of Pharmaceutical Analysis, 6(2), 71-79.

Beata, K.R.ó.L. \& Kiełtyka-Dadasiewicz, A. (2015). Yield and herb quality of thyme (Thymus vulgaris L.) depending on harvest time. Turkish Journal of Field Crops, 20(1), 78-84.

Blois, M. S. (1958). Antioxidant determinations by the use of a stable free radical. Nature, 181(4617), 1199-1200.

Botsoglou, N.A., Grigoropoulou, S. H., Botsoglou, E., Govaris, A. \& Papageorgiou, G. (2003).
The effects of dietary oregano essential oil and $\alpha$-tocopheryl acetate on lipid oxidation in raw and cooked turkey during refrigerated storage. Meat science, 65(3), 1193-1200.

Bounatirou, S., Smiti, S., Miguel, M.G., Faleiro, L., Rejeb, M.N., Neffati, M., ... \& Pedro, L.G. (2007). Chemical composition, antioxidant and antibacterial activities of the essential oils isolated from Tunisian Thymus capitatus Hoff. et Link. Food Chemistry, 105(1), 146-155.

Chang, C., Yang, M., Wen, H. \& Chern, J. (2002). Estimation of Total Flavonoid Content in Propolis by. J Food Drug Anal., 10(3),7802.

Chun, S.S., Vattem, D.A., Lin, Y.T. \& Shetty, K. (2005). Phenolic antioxidants from clonal oregano (Origanum vulgare) with antimicrobial activity against Helicobacter pylori. Process Biochemistry, 40(2), 809-816.

Delgado-Adámez, J., Garrido, M., Bote, M.E., Fuentes-Pérez, M.C., Espino, J. \& MartínVertedor, D. (2017). Chemical composition and bioactivity of essential oils from flower and fruit of Thymbra capitata and Thymus species. Journal of Food Science and Technology, 54(7), 1857-1865.

De Martino, L., Bruno, M., Formisano, C., De Feo, V., Napolitano, F., Rosselli, S. \& Senatore, F. (2009). Chemical composition and antimicrobial activity of the essential oils from two species of Thymus growing wild in southern Italy. Molecules, 14(11), 4614-4624.

Goren, A.C., Bilsel, G., Bilsel, M., Demir, H. \& Kocabaş, E.E. (2003). Analysis of essential oil of Coridothymus capitatus (L.) and its antibacterial and antifungal activity. Zeitschrift für Naturforschung C, 58(9-10), 687-690.

Hussain, T., Arshad, M., Khan, S., Sattar, H. \& Qureshi, M.S. (2011). In vitro screening of methanol plant extracts for their antibacterial activity. Pak. J. Bot, 43(1), 531-538.

Jean, B. (2009). Pharmacognosie, phytochimie, plantes médicinales (4e éd.). Lavoisier: Technique et Documentation; 2009, Paris

Kähkönen, M.P., Hopia, A.I., Vuorela, H.J., Rauha, J.P., Pihlaja, K., Kujala. T.S., \& Heinonen, M. (1999). Antioxidant activity of plant extracts containing phenolic compounds. J Agric Food Chem., 47(10), 3954-3962.

Khan, S., Nazir, M., Raiz, N., Saleem, M., Zengin, G., Fazal, G., ... \& Abdallah, H.H. (2019). Phytochemical profiling, in vitro biological properties and in silico studies on Caragana ambigua stocks (Fabaceae): A comprehensive approach. Industrial Crops and Products, 131, 117-124.

Khalkho, A., Sahu, P., Kumari, S. \& Alam S. (2015). Studies on Ethnomedicinal Uses and Formulation of Herbal Drugs from Medicinal 
Plants of Ranchi District- A Survey. Am J Ethnomedicine, 2, 284-296.

Kılıç S. (2018), Comparison of mineral element amounts of aromatic plant and their oils. GIDA (2018) 43 (4): 617-623 doi: 10.15237/gida.GD18028

Koparal, A.T. \& Zeytinoglu, M. (2003). Effects of carvacrol on a human non-small cell lung cancer (NSCLC) cell line, A549. Cytotechnology, 43(1-3), 149-154.

Llorens, L., Llorens-Molina, J.A., Agnello, S. \& Boira, H. (2014). Geographical and environment-related variations of essential oils in isolated populations of Thymus richardii Pers. in the Mediterranean basin. Biochemical Systematics and Ecology, 56, 246-254.

Ložienė, K., Venskutonis, P.R., Šipailienè, A. \& Labokas, J. (2007). Radical scavenging and antibacterial properties of the extracts from different Thymus pulegioides L. chemotypes. Food Chemistry, 103(2), 546-559.

Mahboubi, M., Heidarytabar, R., Mahdizadeh, E. \& Hosseini, H. (2017). Antimicrobial activity and chemical composition of Thymus species and Zataria multiflora essential oils. Agriculture and Natural Resources, 51(5), 395-401.

Morales, R. (1997). Synopsis of the genus Thymus L. in the Mediterranean area. Lagascalia, 19 (1-2), 249-262.

Markovic, T. (2011). Essential Oils and Their Safe Use. Dr J. Panč. Institute of Medicinal Plant Research.

Njume, C., Afolayan, A.J. \& Ndip, R.N. (2009). An overview of antimicrobial resistance and the future of medicinal plants in the treatment of Helicobacter pylori infections. African Journal of Pharmacy and Pharmacology, 3(13), 685-699.

Oke, F., Aslim, B., Ozturk, S. \& Altundag, S. (2009). Essential oil composition, antimicrobial and antioxidant activities of Satureja cuneifolia Ten. Food Chemistry, 112(4), 874-879.

Özkan, O.E., Olgun, Ç., Güney, B., Gür, M., Güney, K., \& Ateş S. (2018). Chemical composition and antimicrobial activity of Myristica fragrans \& Elettaria cardamomum essential oil. Kastamonu Üniversitesi Orman Fakültesi Dergisi, 18(2), 225-229.

Panizzi, L., Flamini, G., Cioni, P.L. \& Morelli, I. (1993). Composition and antimicrobial properties of essential oils of four Mediterranean Lamiaceae. Journal of Ethnopharmacology, 39(3), 167-170.

Petrović, N.V., Petrović, S.S., Džamić, A.M., Ćrić, A.D., Ristić, M.S., Milovanović, S.L. \& Petrović, S.D. (2016). Chemical composition, antioxidant and antimicrobial activity of Thymus praecox supercritical extracts. The Journal of Supercritical Fluids, 110, 117-125.

Phippen, W.B. \& Simon, J.E. (1998). Anthocyanins in basil (Ocimum basilicum L.). Journal of Agricultural and Food Chemistry, 46(5), 1734-1738.

Ruch, R.J., Cheng, S.J. \& Klaunig, J.E. (1989). Prevention of cytotoxicity and inhibition of intercellular communication by antioxidant catechins isolated from Chinese green tea. Carcinogenesis, 10(6), 1003-1008.

Ruiz-Navajas, Y., Viuda-Martos, M., Sendra, E., Perez-Alvarez, J.A. \& Fernßndez-Ľpez, J. (2012). Chemical characterization and antibacterial activity of Thymus moroderi and Thymus piperella essential oils, two Thymus endemic species from southeast of Spain. Food Control, 27(2), 294-299.

Slinkard, K. \& Singleton, V.L. (1977). Total phenol analysis: automation and comparison with manual methods. American Journal of Enology and Viticulture, 28(1), 49-55.

Stahl-Biskup, E. (1991). The chemical composition of Thymus oils: a review of the literature 1960-1989. Journal of Essential Oil Research, 3(2), 61-82.

Stahl-Biskup, E. (2002). Thyme as a herbal drugpharmacopoeias and other product characteristics. Thyme: the genus thymus, Taylor \& Francis, London, 293.

Stahl-Biskup, E. \& Sáez, F. (Eds.). (2002). Thyme: The Genus Thymus. CRC Press, London: Taylor \& Francis.

Tepe, B., Sokmen, M., Sokmen, A., Daferera, D. \& Polissiou, M. (2005). Antimicrobial and antioxidative activity of the essential oil and various extracts of Cyclotrichium origanifolium (Labill.) Manden. \& Scheng. Journal of Food Engineering, 69(3), 335-342.

Vital, P. G. \& Rivera, W. L. (2011). Antimicrobial activity, cytotoxicity, and phytochemical screening of Voacanga globosa (Blanco) Merr. leaf extract (Apocynaceae). Asian Pacific Journal of Tropical Medicine, 4(10), 824-828.

Zarshenas, M.M. \& Krenn, L. (2015). A critical overview on Thymus daenensis Celak.: phytochemical and pharmacological investigations. Journal of Integrative Medicine, 13(2), 91-98. 